\title{
Two Years After Alice v. CLS Bank
}

\author{
Jasper L. Tran*
}

\section{Contents}

I. Alice at One 3

A. Alice's Recap . . . . . . . . . . . . . . . . . . . . . . . . . 3

B. Alice's One-Year Review . . . . . . . . . . . . . . . . . . . 4

II. Alice at Two 5

A. Alice's Two-Year Statistics ... . . . . . . . . . . . . . . . . . . 5

B. Analysis and Recommendation . . . . . . . . . . . . . . . . 6

III. The Federal Circuit Cases in Alice's Second Year 7

A. Federal Circuit Cases from Alice's One-Year Mark to Pre-Enfish . . . . . . . . . 7

B. Enfish v. Microsoft . . . . . . . . . . . . . . . . . . . . . . . . . . . . 11

C. In re TLI Communications LLC Patent Litigation . . . . . . . . . . . . . . . . . . . 13

D. The USPTO's Reaction Immediately After Enfish and TLI Communications . . 15

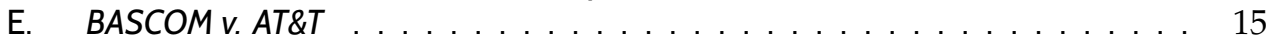

$\begin{array}{ll}\text { IV. Conclusion } & 17\end{array}$

$\begin{array}{ll}\text { Appendix A } & 18\end{array}$

*Judicial Clerk, Google Policy Fellow. Views are my own, in my individual capacity. Email: tran4lr@gmail.com. @ Jasper L. Tran. 


\begin{abstract}
As of June 19, 2016, courts have examined 568 challenged patents brought under $\S 101$ motions citing Alice, resulting in 190 valid patents and 378 patents invalidated with an average invalidation rate of $66.5 \%$. Specifically, the Federal Circuit upheld 3 patents and invalidated 34 patents—an average invalidation rate of $91.9 \%$. Also, courts have decided a total of 500 motions brought under $\S 101$ citing Alice, resulting in 109 validation holdings and 391 invalidation holdings with an average invalidation rate of $78.2 \%$. Specifically, the Federal Circuit has decided 26 motions, resulting in 2 validation holdings and 24 invalidation holdings with an average invalidation rate of $92.3 \%$. The district courts have decided 251 motions, resulting in 84 validation holdings and 167 invalidation holdings with an average invalidation rate of $66.5 \%$. The PTAB has decided 209 motions, resulting in 23 validation holdings and 186 invalidation holdings with an average invalidation rate of $89.7 \%$.
\end{abstract}

Justice Stephen Breyer's recent statement fully captured the U.S. Supreme Court's view on software patents: "[T]here are these [] patent trolls, and [] the Patent Office has been issuing billions of patents that shouldn't have been issued - I overstate, but only some." ${ }^{11}$

On June 19, 2014, the Supreme Court decided Alice Corp. v. CLS Bank Int'l, ${ }^{2}$ raising the patentability standard for computer-implemented inventions under 35 U.S.C. $\S 101$. The Court held that implementing an abstract idea on a computer is not enough to transform that idea into patentable subject matter. ${ }^{3}$ Put simply, Alice was a "noticeable judicial move[] to curb excessive patent assertion," ${ }^{4}$ and $\S 101$ postAlice has proven "deadly" for software patents. ${ }^{5}$ For instance, between July 1 and August 15, 2014 (immediately after Alice), there were 830 patent applications related computer-implemented inventions withdrawn from the U.S. Patent and Trademark Office (“USPTO”). ${ }^{6}$

At Alice's one-year mark, I reviewed all lower court decisions that cited Alice to invalidate software patents. ${ }^{7}$ Specifically, as of June 19, 2015, there were a total of 272 court cases-198 Patent Trial and Appeal Board ("PTAB") decisions, 63 district court decisions, and 11 Federal Circuit opinions-that cited Alice to invalidate software patents, accounting for an average invalidation rate of $82.9 \% .{ }^{8}$ I also estimated that-without accounting for selection bias-out of roughly 240,000 software patents in force as of 2015, about 199,000 of those, if challenged, would likely be invalidated under Alice, leaving about 41,000 actually valid patents. ${ }^{9}$

\footnotetext{
${ }^{1}$ Justice Breyer made this statement on April 25, 2016 during Cuozzo Speed Technologies v. Lee's oral arguments. See Transcript of Oral Argument, p. 14 11. 8-12, Cuozzo Speed Techs., LLC v. Lee, 136 S. Ct. 890 (No. 15-446), available at http://www.supremecourt.gov/oral_arguments/argument_transcripts/15-446_2dp3.pdf.In fact, Alice was a 9-0 decision with 3 concurring justices. Alice Corp. v. CLS Bank Int'l, 134 S. Ct. 2347, 2351 (2014).

${ }^{2} 134$ S. Ct. 2347 (2014).

${ }^{3} I d$. at $2355,2357$.

${ }^{4}$ Christopher Beauchamp, The First Patent Litigation Explosion, 125 Yale L.J. 848, 934 (2016).

${ }^{5}$ Foley Hoag LLP, The Post Office Gets into the Alice Act, PTAB BLog (Oct. 27, 2015), http:/ /www.ptab-blog.com/2015/10/ 27/the-post-office-gets-into-the-alice-act/. For a background discussion on patents, see generally Jasper L. Tran, Timing Matters: Prior Art's Age Infers Patent Nonobviousness, 50 Gonz. L. Rev. 189, 194-97 (2015) (discussing patent nonobviousness and prior arts); Jasper L. Tran, Rethinking Intellectual Property Transactions, 43 S.U. L. Rev. 149, 150-56 (2015) (discussing patent transaction).

${ }^{6}$ See Tristan Gray-Le Coz \& Charles Duan, Apply It to the USPTO: Review of the Implementation of Alice v. CLS Bank in Patent Examination, 2014 Patently-O PAtent L.J. 1, 3 (2014).

${ }^{7}$ Jasper L. Tran, Software Patents: A One-Year Review of Alice v. CLS Bank, 97 J. Рat. \& Trademark Off. Soc'y 532, 539-45 (2015).

${ }^{8}$ Id. at 540 .

${ }^{9}$ Id. at $541-42$.
} 
This Article continues my previous review at Alice's two-year mark. As of June 19, 2016, courts have examined 568 challenged patents brought under $\S 101$ motions citing Alice, resulting in 190 valid patents and 378 patents invalidated with an average invalidation rate of $66.5 \%$. The Federal Circuit has upheld 3 patents and invalidated 34 patents-an average invalidation rate of $91.9 \%$.

Courts have also decided a total of 500 motions brought under $\S 101$ citing Alice, resulting in 109 validation holdings and 391 invalidation holdings with an average invalidation rate of $78.2 \%$. Specifically, the Federal Circuit has decided 26 motions, resulting in 2 validation holdings and 24 invalidation holdings with an average invalidation rate of $92.3 \%$. The district courts have decided 251 motions, resulting in 84 validation holdings and 167 invalidation holdings with an average invalidation rate of $66.5 \%$. The PTAB has decided 209 motions, resulting in 23 validation holdings and 186 invalidation holdings with an average invalidation rate of $89.7 \%$.

The Federal Circuit notably released Enfish, LLC v. Microsoft Corp., ${ }^{10}$ on May 12, 2016, marking the second Federal Circuit decision to uphold patent validity since Alice ${ }^{11}$ and shed more light on how to analyze $\S 101$ under Mayo / Alice. In Enfish, the Federal Circuit made clear that it was "not persuaded that the invention's ability to run on a generalpurpose computer dooms the claims."12 The Federal Circuit then released BASCOM Global Internet Services, Inc. v. AT E T Mobility $L L C^{13}$ on June 27, 2016, marking the third Federal Circuit decision to uphold patent validity since Alice.

This Article proceeds in four parts. Part I quickly recaps the Alice v. CLS Banks decision and Alice's one-year statistics. Part II lays out and analyzes Alice's two-year statistics. Part III reviews the Federal Circuit cases in Alice's second year, including Enfish, TLI Communications, and BASCOM, with a quick coverage of the USPTO's reaction post-Enfish. Part IV concludes. Additionally, Appendix A includes the information of the patents or patent applications that courts have upheld under Alice from June 20, 2015 to June 19, 2016.

\section{Alice at One}

\section{A. Alice's Recap}

My one-year review of Alice discussed Alice's procedural history and opinion in detail. ${ }^{14}$ In short, Alice built on Mayo Collaborative Services v. Prometheus Laboratories, Inc. ${ }^{15}$ and established a two-step framework for patentable subject matter of computer-implemented inventions:

1. The Mayo/Alice step one "determine[s] whether the claims at issue are directed to a patent-ineligible concept. If so, the Court then asks whether the claim's [additional] elements, considered both individually and as an ordered combination,

\footnotetext{
${ }^{10}$ No. 2015-1244, 2016 WL 2756255 (Fed. Cir. May 12, 2016).

${ }^{11}$ The first Federal Circuit decision that upheld patent validity since Alice was DDR Holdings, LLC v. Hotels.com, L.P., 773 F.3d 1245 (Fed. Cir. 2014).

${ }^{12}$ Id. at $* 7$.

${ }^{13}$ No. 2015-1763, 2016 WL 3514158 (Fed. Cir. June 27, 2016).

${ }^{14}$ Tran, One-Year Review, supra note 7, at 535-39.

${ }^{15} 132$ S. Ct. 1289 (2012).
} 
transform the nature of the claim into a patent-eligible application."16

2. The Mayo/Alice step two "examine[s] the elements of the claim to determine whether it contains an inventive concept sufficient to transform the claimed abstract idea into a patent-eligible application. A claim that recites an abstract idea must include additional features to ensure that the claim is more than a drafting effort designed to monopolize the abstract idea."17 Adequate "transformation into a patent-eligible application requires more than simply stating the abstract idea while adding the words 'apply it."'18

In Alice the challenged patents claimed "a computer-implemented scheme for mitigating 'settlement risk' (i.e., the risk that only one party to a financial transaction will pay what it owes) by using a third-party intermediary."19 The Supreme Court found the claims were "directed to a patent-ineligible concept: the abstract idea of intermediated settlement," and were "not enough to supply the inventive concept needed to make th[e] transformation" into a patent-eligible application because the claims did "no more than simply instruct the practitioner to implement the abstract idea of intermediated settlement on a generic computer." ${ }^{20}$

\section{B. Alice's One-Year Review}

Following its $\S 101$ framework in Mayo, ${ }^{21}$ the Supreme Court considered Alice a "minor case." ${ }^{22}$ In fact, CLS Bank—at Alice's oral argument—framed the issue as "a very small problem" that would only impact the "most marginal, most dubious, most skeptical patents," citing the statistics of 57 district court on $\S 101$ and 12 Federal Circuit cases on computer implementation in the four years following Bilski. ${ }^{23}$ But the reality post-Alice has unfolded in the opposite direction.

Following Alice, the USPTO issued the 2014 Interim Guidance on Patent Subject Matter Eligibility to examiners on implementing Alice. ${ }^{24}$ The 2014 Guidance allowed software claims of either "[i]mprovements to another technology or technical field; [i]mprovements to the functioning of the computer itself; [or m] eaningful limitations beyond generally linking the use of an abstract idea to a particular technological environment." 25

Between July 1 and August 15, 2014, there were 830 patent applications related computer-implemented inventions withdrawn from the U.S. Patent and Trademark

\footnotetext{
${ }^{16}$ Alice Corp. Pty. v. CLS Bank Int'1, 134 S. Ct. 2347, 2350 (2014) (citing Mayo Collaborative Servs. v. Prometheus Labs., Inc., 132 S. Ct. 1289, 1291 (2012)) (internal quotations omitted).

${ }^{17}$ Id. at 2357 (citing Mayo, 132 S. Ct. at 1294, 1297-98) (internal quotations omitted).

${ }^{18} \mathrm{Id}$. (some internal quotations omitted).

${ }^{19} I d$. at $2351-52$.

${ }^{20}$ Id. at 2350-51, 2357 (internal quotations omitted).

${ }^{21}$ Mayo Collaborative Servs. v. Prometheus Labs., Inc., 132 S. Ct. at 1289 (2012).

${ }^{22}$ Robert R. Sachs, Two Years After Alice: A Survey of the Impact of a "Minor Case," Part I, Bilski Blog (June 16, 2016), http: //www.bilskiblog.com/blog/2016/06/two-years-after-alice-a-survey-of-the-impact-of-a-minor-case.html (last visited June 20, 2016) (citing a conversation with a Supreme Court Justice).

${ }^{23}$ Transcript of Oral Argument, pp. 43-44, Alice Corp. Pty. v. CLS Bank Int'1, 134 S.Ct. 2347 (No. 13-298), available at http://www.supremecourt.gov/oral_arguments/argument_transcripts/13-298_869d.pdf.

${ }^{24}$ Memorandum from Andrew H. Hirschfield, Deputy Comm'r of the U.S. Pat. \&Trademark Off. to Patent Examiners (June 25, 2014), available at http://www.uspto.gov/sites/default/files/patents/announce/alice_pec_25jun2014.pdf.

${ }^{25} I d$.
} 
Office ("USPTO"). ${ }^{26}$ By December 15, 2014, there were 36 lower court cases-32 in the district courts and 4 in the Federal Circuit-that cited Alice to invalidate software patents. $^{27}$

By June 19, 2015 (Alice's one-year mark), the case was cited in 190 PTAB decisions, 60 district court decisions, and 9 Federal Circuit opinions, in a total of 261 court cases, to invalidate patents under $\S 101 .^{28}$ Specifically, the PTAB upheld 18 patent applications and invalidated 170 patent applications-an invalidation rate of $90.4 \%{ }^{29}$ The district courts upheld 40 patents and invalidated 89 patents-an invalidation rate of $69.0 \%{ }^{30}$ The Federal Circuit upheld 1 patent and invalidated 14 patents-an invalidation rate of $93.3 \%{ }^{31}$ In total, 273 invalidations out of 332 patents or patent applications yield an average invalidation rate of $82.2 \%$ before the three venues. ${ }^{32}$

\section{II. $\quad$ Alice at Two}

\section{A. Alice's Two-Year Statistics}

By the end of 2015, patent grants had dropped for the first time in seven years, "a drop likely attributable to the Alice decision's impact on obtaining and asserting software patents," according to an annual study by PricewaterhouseCoopers analysts. ${ }^{33}$

Under the Mayo / Alice standard, patents' validity can be challenged in district court under $\S 101$ motions. Table 1 shows the statistics of courts' implementation of Alice from June 19, 2014 to June 19, 2016. ${ }^{34}$

Patents. As of June 19, 2016 (i.e. Alice's two-year mark), courts have examined 568 challenged patents brought under $\S 101$ motions citing Alice, resulting in 190 valid patents and 378 patents invalidated with an average invalidation rate of $66.5 \%$. Specifically, the Federal Circuit upheld 3 patents and invalidated 34 patents-an average invalidation rate of $91.9 \%$. The UPSTO has rejected over 36,000 published patent applications

\footnotetext{
${ }^{26}$ See Gray-Le Coz \& Duan, supra note 6, at 3.

${ }^{27}$ See Jennifer A. Albert et al., Impact of the Alice V. CLS Bank Decision - A Year-End Review, Goodwin Procter: IP Alert (Dec. 19, 2014), http://www.goodwinprocter.com/Publications/Newsletters/IP-Alert/2014/1219-Impact-of-the-Alice-V-CLSBank-Decision.aspx?article $=1$.

${ }^{28}$ Tran, One-Year Review, supra note 7, at 540.

${ }^{29} \mathrm{Id}$.

${ }^{30}$ Id.

${ }^{31} I$ d.

${ }^{32} \mathrm{Id}$.

${ }^{33}$ Kevin Penton, Patent Grants Dropped For First Time In 7 Years, Report Says, Law360 (May 17, 2016), http:/ /www.law360. com/ip/articles/797381. Note that in May 2016, President Obama signed the Uniform Trade Secret Act into law, which creates a federal cause of action for trade secret infringement and could affect the landscape of patent filing in the future. The Defend Trade Secrets Act of 2015, S. 1890, H.R. 3326, 114th Cong. (2015).

${ }^{34}$ Methodology note: Using WestlawNext, I searched for all cases citing Alice from June 19, 2014 to June 19, 2016. In performing my research, I compared my own data on Alice with the data of Fenwick \& West's Bilski Blog. Sachs, Part I, supra note 22, at tbl. 1 (containing table and chart); see also Decoding Patent Eligibility Post-Alice: Patent Eligibility Case Analysis Tool, Fenwick \& West LLP, https://www.fenwick.com/pages/post-alice.aspx (last visited May 18, 2016) (containing the case names, holdings, and reasonings of cases decided in 2015 and the latter half of 2014 ). To explain the minor disagreement between the two sets of data: my collection included data of cases until June 19, 2016 to meet the actual two-year anniversary date of Alice whereas Sachs' set of data ended on June 8, 2016. See also Jason Rantanen, Empirical Analyses of Judicial Opinions: Methodology, Metrics and the Federal Circuit, 49 ConN. L. Rev. _ (forthcoming 2016), available at http://ssrn.com/abstract= 2774307 (examining how to consider reported data in collective terms and discussing substantial variation of reported empirical results even when using the same parameter to measure).
} 


\begin{tabular}{|c|c|c|c|c|c|c|c|}
\hline \multicolumn{2}{|c|}{$\begin{array}{c}\text { June 19, 2014 to } \\
\text { June 19, 2016 }\end{array}$} & \multicolumn{4}{|c|}{ § 101 motions } & \multicolumn{2}{c|}{ Patents } \\
\cline { 2 - 8 } & Fed. Cir. & Distr. Ct. & PTAB & Total & Fed. Cir. & Total \\
\hline \multirow{3}{*}{ Holding } & Invalid & 24 & 167 & 200 & 391 & 34 & 378 \\
\cline { 2 - 8 } & Valid & 2 & 84 & 23 & 109 & 3 & 190 \\
\cline { 2 - 8 } & Total & 26 & 251 & 223 & 500 & 37 & 568 \\
\hline Invalidation Rate & $92.3 \%$ & $66.5 \%$ & $89.7 \%$ & $78.2 \%$ & $91.9 \%$ & $66.5 \%$ \\
\hline
\end{tabular}

Table 1: Alice statistics from June 19, 2014 to June 19, 2016.

under Alice, where over 5,000 such applications were abandoned. ${ }^{35}$

$\S 101$ Motions. Courts decided a total of 500 motions brought under $\S 101$ citing $\mathrm{Al}$ ice, resulting in 109 validation holdings and 391 invalidation holdings with an average invalidation rate of $78.2 \%$. Specifically, the Federal Circuit decided 26 motions, which resulted in 2 validation holdings and 24 invalidation holdings with an average invalidation rate of $92.3 \%$. The district courts decided 251 motions, resulting in 84 validation holdings and 167 invalidation holdings with an average invalidation rate of $66.5 \%$. The PTAB decided 209 motions, resulting in 23 validation holdings and 186 invalidation holdings with an average invalidation rate of $89.7 \%$.

\section{B. Analysis and Recommendation}

Alice's invalidation rate seemed to slightly drop through Alice's second year, but the drop was almost unnoticeable. ${ }^{36}$ Individually, the invalidation rate ranged from $66 \%$ to $93 \%$, which remains very high. Before three venues, namely the district courts, the PTAB and the Federal Circuit, the average invalidation rate was $82.9 \%$ at Alice's oneyear ${ }^{37}$ and $78.2 \%$ at Alice's two-year. Given that Enfish and BASCOM came out very late toward the end of Alice's second year, a determination of whether Enfish and BASCOM (in combination with DDR Holdings) affect Alice's interpretation will have to wait until Alice's third-year review.

At Alice's first year, the Federal Circuit has the highest invalidation rate at $93.3 \%$ with the PTAB immediately behind at $90.4 \%$, whereas the district courts have the lowest invalidation rate of $69.0 \%$. The numbers remain similar at Alice's second year review, where the Federal Circuit had the highest invalidation rate at $92.3 \%$ with the PTAB immediately behind at $89.7 \%$, whereas the district courts again had the lowest invalidation rate of $66.4 \%$. Because the PTAB continues to aggressively implement Alice, ${ }^{38}$ my rec-

\footnotetext{
${ }^{35}$ Robert R. Sachs, Two Years After Alice: A Survey of the Impact of a "Minor Case" (Part 2), Bilski Blog (June 20, 2016), http://www.bilskiblog.com/blog/2016/06/two-years-after-alice-a-survey-of-the-impact-of-a-minor-case.html (last visited July 20, 2016). Sachs further noted: "Actually, it's worse than that because statistics presented here are based on published applications, which have historically accounted for $60 \%$ of all patent applications. It is reasonable to assume that unpublished applications get the same treatment with respect to $\S 101$ as published ones. The upshot: the actual number of applications rejected due to Alice is likely closer 60,000, and the number abandoned is likely closer to 8,400." Id. at n.1.

${ }^{36}$ Tran, One-Year Review, supra note 7, at 541.

${ }^{37}$ Id. at 540 .

${ }^{38}$ Id. at 541; see also Albert, supra note 27 (arriving at the same conclusion). Note that the sample size of the $\S 101$ motions at the Federal Circuit remains insufficiently small $(n=26)$ to fully predict its behavior, thus the opinions may not be wholly indicative of the Federal Circuit's view on software patents. For a tally on how the Federal Circuit judges have voted on $\S 101$ since Alice, see Sachs, Part I supra note 22, at fig. 3. However, this does not apply to the PTAB $(n=223)$ and the district courts $(n=251)$, where their larger sample sizes could sufficiently predict the cases' outcomes at the PTAB and the district courts.
} 
ommendation remains the same: Plaintiffs should file an invalidation motion at the PTAB, whereas defendants should defend patent validity at the district court. ${ }^{39}$

\section{The Federal Circuit Cases in Alice's Second Year}

\section{A. Federal Circuit Cases from Alice's One-Year Mark to Pre-Enfish}

In Internet Patents Corp., v. Active Network, Inc. ${ }^{40}$ (June 23, 2015), the district court characterized the challenged patent as claiming "the use of a conventional web browser Back and Forward navigational functionalities without data loss in an online application consisting of dynamically generated web pages." 41 The Federal Circuit found the claims directed to ineligible subject matter because they "represent merely generic data collection steps or siting the ineligible concept in a particular technological environment." ${ }^{2}$ In other words, the claims here were directed to the abstract idea of maintaining computer state without recitation of specific activity used to generate that result.

In Intellectual Ventures I LLC, v. Capital One Bank (USA) ${ }^{43}$ (July 6, 2015), the two patents at issue claimed (1) "methods of budgeting, particularly methods of tracking and storing information relating to a user's purchases and expenses and presenting that information to the user vis-à-vis the user's pre-established, self-imposed spending limits," and (2) "methods and systems for providing customized web page content to the user as a function of user-specific information and the user's navigation history." 44 The Federal Circuit found the first patent "directed to an abstract idea: tracking financial transactions to determine whether they exceed a pre-set spending limit (i.e., budgeting), . . . [and] the budgeting calculations . . . 'could still be made using a pencil and paper' with a simple notification device even in real time as expenditures were being made." 45 Likewise, the Federal Circuit found that the second patent "claim[s] an abstract idea and do[es] not otherwise claim an inventive concept." In short, the claims simply added generic computer components to financial budgeting. Notably, the Federal Circuit in Intellectual Ventures I held in dicta that the "claims here do not address problems unique to the Internet, so DDR has no applicability." 46 This statement of the Federal Circuit ${ }^{47}$ essentially narrows $D D R^{\prime}$ s holding to only claims "address[ing] prob-

\footnotetext{
${ }^{39}$ Tran, One-Year Review, supra note 7, at 541.

${ }^{40} 790$ F.3d 1343 (Fed. Cir. 2015). For a thorough treatment of the Federal Circuit cases in Alice's first year, see generally Tran, One-Year Review, supra note 7, at 542-45.

${ }^{41} I d$. at 1344 (citing Dist. Ct. Op. at 1269). The district court described the challenged patent "subject matter as retaining information lost in the navigation of online forms," and deemed it as an abstract concept ineligible for patenting. Id. at 1344 .

${ }^{42}$ Id. at 1349.

${ }^{43} 792$ F.3d 1363 (Fed. Cir. 2015).

${ }^{44} I d$. at 1365.

${ }^{45}$ Id. at $1367-69$ (internal citations omitted).

${ }^{46}$ Id. at 1371 (citing DDR Holdings, LLC v. Hotels.com, L.P., 773 F.3d 1245, 1256-69 (Fed. Cir. 2014)). Recall DDR Holdings, LLC v. Hotels.com, L.P. was one of the only two opinions that the Federal Circuit has ever upheld patent-eligibility of a computer-implemented invention under Alice. DDR, 773 F.3d 1245 (Fed. Cir. 2014). DDR's patent covers "systems and methods of generating a composite web page that combines certain visual elements of a 'host' website with content of a third-party merchant." Id. at 1248 .

${ }^{47}$ It might be important to note that a panel of Judges Dyk, Reyna and Chen resided over this case, with Judge Dyk writing for the Court, thus this view on DDR might only represent their own views and not of all Federal Circuit judges. Intellectual Ventures I, 792 F.3d at 1365.
} 
lems unique to the Internet." 48

In Versata Development Group, Inc., v. SAP America, Inc. ${ }^{49}$ (July 9, 2015), the challenged "invention operate[d] under the paradigm of WHO (the purchasing organization) is buying WHAT (the product)." 50 The Federal Circuit found that the claimed invention was "a covered business method patent as that term is understood, and it does not fall within the meaning of a 'technological invention."'51 The Federal Circuit invalidated the CMB patent as the computer performed "purely conventional" steps to carry out an "abstract idea of determining a price using organization and product group hierarchies." ${ }^{2}$

In Morales v. Square, Inc. ${ }^{53}$ (October 16, 2015), the challenged patent claimed a "system [which] allows viewers of television programs to respond to offers for products and services displayed on the television screen using a remote control." ${ }^{\prime \prime 4}$ The Federal Circuit, via a one-line order, ${ }^{55}$ affirmed the district court's invalidation of the claims as "an abstract idea because it describes the fundamental concept of relaying a signal containing the sender's identity." ${ }^{16}$ The district court viewed the claims as "simply too broadly drawn to withstand the scrutiny required by the Supreme Court's admonition that patents not impede innovation by preempting the basic tools of scientific and technological work." ${ }^{57}$ The U.S. Supreme Court denied certiorari review on March 21, $2016 .^{58}$

In Cloud Satchel, LLC v. Barnes \& Noble, Inc. ${ }^{59}$ (December 17, 2015), the challenged "patents are directed to systems, devices, and methods for enabling the transmission and storage of document references or 'tokens,' each of which is associated with an electronic document stored in a database." ${ }^{60}$ The Federal Circuit, via a one-line order, ${ }^{61}$ affirmed the district court's invalidation of the claims as abstract idea because the "[p]laintiff [was] unable to meaningfully address the fact that the specification unambiguously states that the portable electronic reference transport device may be any 'suitable' portable computer, [nor was] plaintiff able to address the fact that the specification states that the electronic document reference may appear in 'any suitable format' and the distributed document subsystem consists of purely 'conventional' elements

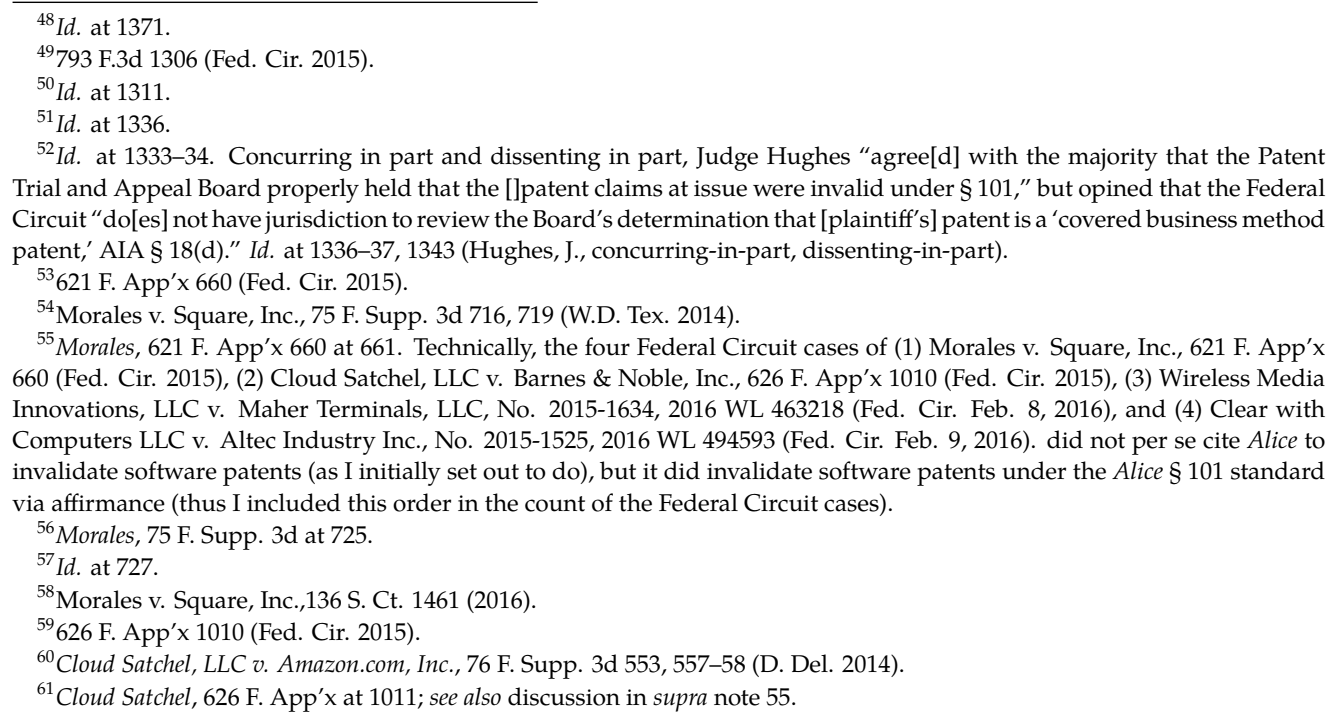


connected by a 'conventional' network."62 The U.S. Supreme Court denied certiorari review on April 25, 2016. ${ }^{63}$

In Vehicle Intelligence \& Safety LLC v. Mercedes-Benz USA, LLC ${ }^{64}$ (December 28, 2015), the challenged "patent claims methods and systems that screen equipment operators for impairment, selectively test those operators, and control the equipment if an impairment is detected." ${ }^{65}$ The Federal Circuit found the claims "drawn to a patent-ineligible concept, specifically the abstract idea of testing operators of any kind of moving equipment for any kind of physical or mental impairment" because "[n]one of the claims at issue are limited to a particular kind of impairment, explain how to perform either screening or testing for any impairment, specify how to program the 'expert system' to perform any screening or testing, or explain the nature of control to be exercised on the vehicle in response to the test results." 66 Furthermore, the Federal Circuit found "[n]othing in these claims-considered as individual elements or an ordered combination-disclose an inventive concept sufficient to transform the abstract idea of testing operators of any kind of moving equipment for any kind of physical or mental impairment into a patent-eligible application of that idea." ${ }^{67}$ The Supreme Court denied certiorari review on May 31, 2016. ${ }^{68}$

In Mortgage Grader, Inc. v. First Choice Loan Services Inc. ${ }^{69}$ (January 20, 2016), the challenged claims were "directed to systems and methods for assisting borrowers to obtain loans." ${ }^{70}$ The Federal Circuit invalidated the claims as "directed to the abstract idea of 'anonymous loan shopping"' because the claims "recite nothing more than the collection of information to generate a 'credit grading' and to facilitate anonymous loan shopping," and simply "'add' only generic computer components such as an 'interface,' 'network,' and 'database."'71 Notably, the Federal Circuit again reiterated DDR's claims as "solv[ing] a problem unique to the Internet."72

In Wireless Media Innovations, LLC v. Maher Terminals, LLC ${ }^{73}$ (February 8, 2016), the two challenged patents claimed "a system for monitoring shipping containers, . . . 5 steps for monitoring the location and load status of shipping containers, . . . a computerized system for monitoring and recording location and load status of shipping containers relative to a facility, . . . [and] steps for generating a report for monitoring containers to be unloaded without first being placed in a yard at the container facility." ${ }^{17}$ The Federal Circuit, via a one-line order, ${ }^{75}$ affirmed the district court's invalidation of the claims as "directed to the same abstract idea: monitoring locations, movement, and load status of shipping containers within a container-receiving yard,

\footnotetext{
${ }^{62}$ Cloud Satchel, 76 F. Supp. 3d at 564 (internal citations omitted).

${ }^{63}$ Cloud Satchel, LLC v. Barnes \& Noble, Inc., No. 15-1161, 2016 WL 1059941 (U.S. Apr. 25, 2016).

${ }^{64}$ No. 2015-1411, 2015 WL 9461707 (Fed. Cir. Dec. 28, 2015).

${ }^{65} \mathrm{Id}$. at ${ }^{*} 1$.

${ }^{66}$ Id. at *2 (analyzing under Mayo/Alice step one).

${ }^{67}$ Id. at *3 (analyzing under Mayo/Alice step two).

${ }^{68}$ Vehicle Intelligence \& Safety LLC v. Mercedes-Benz USA, LLC, No. 15-1201, 2016 WL 1171121 (U.S. May 31, 2016).

${ }^{69} 811$ F.3d 1314 (Fed. Cir. 2016).

${ }^{70}$ Id. at 1318.

${ }^{71}$ Id. at 1324 .

${ }^{72}$ Id. at 1325 (citing DDR Holdings, LLC v. Hotels.com, L.P., 773 F.3d 1245, 1257 (Fed. Cir. 2014)); see also discussion in supra note 46.

${ }^{73}$ No. 2015-1634, 2016 WL 463218 (Fed. Cir. Feb. 8, 2016).

${ }^{74}$ Wireless Media Innovations, LLC v. Maher Terminals, LLC, 100 F. Supp. 3d 405, 414-15 (D.N.J. 2015).

${ }^{75}$ Wireless Media, 2016 WL 463218 at ${ }^{*} 1$; see also discussion in supra note 55.
} 
and storing, reporting and communicating this information in various forms through generic computer functions." 76

In Clear with Computers LLC v. Altec Industry Inc. ${ }^{77}$ (February 9, 2016), "[t]he patentsin-suit relate to computer-implemented systems and methods for creating a sales proposal." ${ }^{78}$ The Federal Circuit, again via a one-line order, ${ }^{79}$ affirmed the district court's invalidation of "the asserted claims [as] directed to the abstract idea of creating a customized sales proposal for a customer." ${ }^{80}$ The district court acknowledged that "the contours are often unclear between those inventions that are directed to an abstract idea and those that are not," but found "the claims in this particular case plainly fall within the category of claims that, without some additional inventive concept, are directed to abstract ideas which are ineligible for patent protection." ${ }^{81}$ Notably, the district court in Clear with Computers made "clear [that it] does not hold that all claims in softwarebased patents are directed to an abstract idea, ${ }^{82}$ which is consistent with the Federal Circuit's view in Enfish. ${ }^{83}$

In In re Smith ${ }^{84}$ (March 10, 2016), the challenged invention "relate[d] to a wagering game utilizing real or virtual standard playing cards." 85 The Federal Circuit affirmed the rejection of the invalid claims as "directed to rules for conducting a wagering game, compare to other 'fundamental economic practices' found abstract by the Supreme Court" because the claimed "method of conducting a wagering game [here] is drawn to an abstract idea much like Alice's method of exchanging financial obligations and Bilski's method of hedging risk." 86 Notably, the Federal Circuit declined to review the USPTO's 2014 Interim Guidance on Patent Subject Matter Eligibility to examiners on how to apply Alice because the Interim Eligibility Guidance "is not intended to create any right or benefit, substantive or procedural, enforceable by any party against the Office, [but] Rejections will continue to be based upon the substantive law, and it is these rejections that are appealable." 87

In Genetic Techs. Ltd. v. Merial L.L.C. ${ }^{88}$ (April 8, 2016), the challenged "patent claim[ed] methods of analyzing sequences of genomic deoxyribonucleic acid ('DNA')." ${ }^{89}$ Citing to Ariosa Diagnostics, Inc. v. Sequenom, Inc. ${ }^{90}$ and In re BRCA1- E

\footnotetext{
${ }^{76}$ Wireless Media, 100 F. Supp. 3d at 413.

${ }^{77}$ No. 2015-1525, 2016 WL 494593 (Fed. Cir. Feb. 9, 2016).

${ }^{78}$ Clear with Computers, LLC v. Altec Indus., Inc., No. 6:14-CV-79, 2015 WL 993392 (E.D. Tex. Mar. 3, 2015). It might be important to note that this case is from Judge Rodney Gilstrap's docket. Id. See generally Daniel Klerman \& Greg Reilly, Forum Selling, 89 S. CAL. L. Rev. 241 (2016), for a discussion of Judge Gilstrap's patent docket, who resides over roughly a quarter of all patent cases filed in the United States.

${ }^{79}$ Clear with Computers, 2016 WL 494593 at *1; see also discussion in supra note 55.

${ }^{80}$ Clear with Computers, 2015 WL 993392 at *4.

${ }^{81} \mathrm{Id}$.

${ }^{82} \mathrm{Id}$.

${ }^{83}$ See Enfish, LLC v. Microsoft Corp., No. 2015-1244, 2016 WL 2756255, at *7 (Fed. Cir. May 12, 2016) (stating “we are not persuaded that the invention's ability to run on a general-purpose computer dooms the claims").

${ }^{84} 815$ F.3d 816 (Fed. Cir. 2016).

${ }^{85} \mathrm{Id}$. at 817 .

${ }^{86}$ Id. at 818-19. The Federal Circuit further noted that a "wagering game is, effectively, a method of exchanging and resolving financial obligations based on probabilities created during the distribution of the cards." Id.

${ }^{87}$ Id. at 819 (quoting Interim Eligibility Guidance, 79 Fed. Reg. 74618, 74619 (Dec. 16, 2014)).

${ }^{88}$ No. 2015-1202, 2016 WL 1393573 (Fed. Cir. Apr. 8, 2016).

${ }^{89}$ Id. at ${ }^{*} 1$.

${ }^{90} 788$ F.3d 1371, 1373 (Fed. Cir. 2015) (invalidating patent claiming certain methods of using cell-free fetal DNA ('cffDNA')). The Supreme Court denied certiorari review on June 27, 2016. Sequenom, Inc. v. Ariosa Diagnostics, Inc., No. 15-1182, 2016 WL 1117246 (U.S. June 27, 2016).
} 
BRCA2-Based Hereditary Cancer Test ${ }^{91}$ as "instructive," the Federal Circuit nixed this non-coding gene sequencing patent as "directed to patent-ineligible subject matter" because the challenged patent was "directed to the relationship between non-coding and coding sequences in linkage disequilibrium and the tendency of such non-coding DNA sequences to be representative of the linked coding sequences-a law of nature." ${ }^{92}$

In In re Brown" 93 (April 22, 2016), the challenged invention "claims methods of cutting hair." ${ }^{\prime 94}$ The Federal Circuit invalidated the claims as "drawn to the abstract idea of assigning hair designs to balance head shape" "coupled with routine and conventional hair-cutting steps." ${ }^{\prime 95}$

\section{B. Enfish v. Microsoft}

As of June 19, 2016, the Federal Circuit has only issued two opinions that upheld the patent-eligibility of a software invention under Alice: (1) DDR Holdings, LLC v. Hotels.com, L.P. ${ }^{96}$ (Dec. 5, 2014), and (2) Enfish, LLC v. Microsoft Corp. ${ }^{97}$ (May 12, 2016). $D D R$ was covered in depth in my one-year review of Alice. ${ }^{98}$ On June 27, 2016, the Federal Circuit issued a third opinion that upheld the patent-eligibility of a software invention under Alice: BASCOM Global Internet Services, Inc. v. AT \& T Mobility LLC, ${ }^{99}$ which is covered in depth in Part III.E.

In Enfish, LLC v. Microsoft Corp. ${ }^{100}$ (May 12, 2016), the two patents at issue were "directed to an innovative logical model for a computer database, . . . [that] includes all data entities in a single table, with column definitions provided by rows in that same table, . . . as the 'self-referential' property of the database." ${ }^{101}$ The district court found the claims were "directed to the abstract idea of 'storing, organizing, and retrieving memory in a logical table' or, more simply, 'the concept of organizing information using tabular formats."'102

Conversely, the Federal Circuit found "the plain focus of the claims is on an improvement to computer functionality itself, not on economic or other tasks for which a computer is used in its ordinary capacity."103 The claimed "self-referential table . . . is a specific type of data structure designed to improve the way a computer stores and retrieves data in memory."104 Furthermore, the patent "specification's disparagement of conventional data structures, combined with language describing the 'present

\footnotetext{
${ }^{91} 774$ F.3d 755, 757 (Fed. Cir. 2014) (invalidating patents "cover[ing] compositions of matter and methods relating to the BRCA1 and BRCA2 genes").

${ }^{92}$ Id. at ${ }^{*} 4,{ }^{* 9}$.

${ }^{93}$ No. 2015-1852, 2016 WL 1612776 (Fed. Cir. Apr. 22, 2016).

${ }^{94}$ Id. at ${ }^{*} 1$; see also Michael S. Kwun, Alice Tells a Joke, 19 GreEn BAG 2D 329 (2016).

${ }^{95}$ In re Brown, 2016 WL 1612776 at ${ }^{*} 1, * 2$.

${ }^{96} 773$ F.3d 1245 (Fed. Cir. 2014).

${ }^{97}$ No. 2015-1244, 2016 WL 2756255 (Fed. Cir. May 12, 2016).

${ }^{98}$ See Tran, One-Year Review, supra note 7, at 544-45.

${ }^{99}$ No. 2015-1763, 2016 WL 3514158 (Fed. Cir. June 27, 2016).

${ }^{100}$ No. 2015-1244, 2016 WL 2756255 (Fed. Cir. May 12, 2016). It might be important to note that Judges Hughes, Moore, and Taranto resided over this case, with Judge Hughes writing for the Court. Id. Five days later, Judge Hughes also wrote for the court in In re TLI Communications LLC Patent Litigation, No. 2015-1372, 2016 WL 2865693 (Fed. Cir. May 17, 2016), a decision that came out in the opposite direction from Enfish.

${ }^{101}$ Id. at ${ }^{*} 1$.

${ }^{102}$ Id. at ${ }^{*} 6$.

${ }^{103} I d$. at $* 5$.

${ }^{104} I$. at ${ }^{*} 8$.
} 
invention' as including the features that make up a self-referential table, confirm that our characterization of the 'invention' for purposes of the $\S 101$ analysis has not been deceived by the 'draftsman's art."'105 The Federal Circuit characterized the claims here as "directed to an improvement in the functioning of a computer" and as "directed to a specific improvement to computer functionality" to distinguish Enfish from precedents that invalidated software patents as abstract ideas. ${ }^{106}$ The Federal Circuit found the claims here "not simply directed to any form of storing tabular data, but instead are specifically directed to a self-referential table for a computer database."107 Put simply, the Federal Circuit was "not faced with a situation where general-purpose computer components are added post-hoc to a fundamental economic practice or mathematical equation. Rather, the claims were directed to a specific implementation of a solution to a problem in the software arts."108 Accordingly, the Federal Circuit found the claims were "not directed to an abstract idea within the meaning of Alice. Rather, they were directed to a specific improvement to the way computers operate, embodied in the selfreferential table." 109

Notably (but unsurprisingly), the Federal Circuit was "not persuaded that the invention's ability to run on a general-purpose computer dooms the claims." ${ }^{\prime 10}$ Unlike the lower courts, the Federal Circuit in Enfish "do[es] not read Alice to broadly hold that all improvements in computer-related technology are inherently abstract and, therefore, must be considered at [Mayo/Alice] step two. . . . . [nor] think that claims directed to software, as opposed to hardware, are inherently abstract and therefore only properly analyzed at the second step of the Alice analysis." ${ }^{111}$ Indeed, "[m]uch of the advancement made in computer technology consists of improvements to software that, by their very nature, may not be defined by particular physical features but rather by logical structures and processes. [The Federal Circuit] do not see in Bilski or Alice, or [their] cases, an exclusion to patenting this large field of technological progress."112

The Enfish analysis reframes the Mayo/Alice step one inquiry into a bright-line dichotomy of "whether the focus of the claims is on the specific asserted improvement in computer capabilities . . . or, instead, on a process that qualifies as an "abstract idea" for which computers are invoked merely as a tool."113 In other words, the Enfish framework asks: "is the claimed invention something that makes a computer work better? Or are computers merely being used to do another task?"114 The former is patentable; whereas the latter is fails under Mayo / Alice step two. ${ }^{115}$ The Federal Circuit's Enfish framework signifies a huge departure from "the Supreme Court's rejection of 'categorical rules' to decide subject matter eligibility [as in] Bilski v. Kappos."116 
Central to Enfish is the Federal Circuit's recognition of what is not patentable subject matter. ${ }^{117}$ To distinguish the Enfish claims, the Federal Circuit listed the precedents:

[T] he claims at issue in Alice and Versata can readily be understood as simply adding conventional computer components to well-known business practices. See Alice, 134 S. Ct. at 2358-60; Versata, 793 F.3d at 1333-34 (computer performed "purely conventional" steps to carry out claims directed to the "abstract idea of determining a price using organization and product group hierarchies"); see also Mortgage Grader, 811 F.3d at 1324-25 (claims attaching generic computer components to perform "anonymous loan shopping" not patent eligible); Intellectual Ventures I, 792 F.3d at 1367-69 (claims adding generic computer components to financial budgeting); OIP Techs., 788 F.3d at 1362-64 (claims implementing offer-based price optimization using conventional computer activities); Ultramercial, Inc. v. Hulu, LLC, 772 F.3d 709, 714-17 (Fed. Cir. 2014) (claims applying an exchange of advertising for copyrighted content to the Internet); buySAFE, Inc. v. Google, Inc., 765 F.3d 1350, 1354-55 (Fed. Cir. 2014) (claims adding generic computer functionality to the formation of guaranteed contractual relationships). And unlike the claims here that are directed to a specific improvement to computer functionality, the patent-ineligible claims at issue in other cases recited use of an abstract mathematical formula on any general purpose computer, see Gottschalk v. Benson, 409 U.S. 63, 93 (1972), see also Alice, 134 S. Ct. at 2357-58, or recited a purely conventional computer implementation of a mathematical formula, see Parker v. Flook, 437 U.S. 584, 594 (1978); see also Alice, 134 S. Ct. at 2358, or recited generalized steps to be performed on a computer using conventional computer activity, see Internet Patents, 790 F.3d at 1348-49 (claims directed to abstract idea of maintaining computer state without recitation of specific activity used to generate that result), Digitech Image Techs., LLC v. Electrs. For Imaging, Inc., 758 F.3d 1344, 1351 (Fed. Cir. 2014) (claims directed to abstract idea of "organizing information through mathematical correlations" with recitation of only generic gathering and processing activities). ${ }^{118}$

\section{In re TLI Communications LLC Patent Litigation}

In In re TLI Communications LLC Patent Litigation ${ }^{119}$ (May 17, 2016, five days after Enfish), the challenged patent claimed "an apparatus for recording of a digital image, communicating the digital image from the recording device to a storage device, and to admin-

\footnotetext{
Kappos, 561 U.S. 604, 610 (2010)).

${ }^{117}$ Rantanen, supra note 114 . The Enfish "opinion does not try to fight the idea that there is some subject matter that is not patentable. Instead, it acknowledges that there are limits on patentable subject matter and works with those limits. [The Federal Circuit] considers the precedents in this area and identifies them as fundamentally involving the use of a computer as a general-purpose tool. By defining what is not patentable subject matter in this way, [the Federal Circuit] is freed to identify some 'other' that is outside that impermissible category: developments that improve on the operation of the computer itself." See Rantanen, supra note 114.

${ }^{118}$ Enfish, 2016 WL 2756255, at *7 (some internal citations were modified to shorten the block quote).

${ }^{119}$ No. 2015-1372, 2016 WL 2865693 (Fed. Cir. May 17, 2016). It might be important to note that Judges Hughes, Dyk, and Schall resided over this case, with Judge Hughes again writing for the Court (Judge Hughes also penned the Enfish opinion, see discussion in supra, note 100). TLI Communications, 2016 WL 2865693.
} 
istering the digital image in the storage device." ${ }^{120}$ The Federal Circuit analyzed the claims under the new Enfish framework, "ask[ing] whether the claims are directed to an improvement to computer functionality versus being directed to an abstract idea."121 Unlike the Enfish claims, the Federal Circuit found the claims were "not directed to a specific improvement to computer functionality, [but r]ather, they are directed to the use of conventional or generic technology in a nascent but well-known environment, without any claim that the invention reflects an inventive solution to any problem presented by combining the two."122 In other words, the claims here are "simply directed to the abstract idea of classifying and storing digital images in an organized manner," and "fail to recite any elements that individually or as an ordered combination transform the abstract idea of classifying and storing digital images in an organized manner into a patent-eligible application of that idea."123

In addition to defining what is not patentable subject matter in Enfish, the Federal Circuit in TLI Communications contours some characteristics of what is patentable subject matter, such as "a solution to a 'technological problem' as was the case in Diamond v. Diehr" or an "attempt to solve a challenge particular to the Internet [as in] DDR Holdings." ${ }^{124}$ Given the contrasting opinions of Enfish and TLI Communications, future Federal Circuit opinions (or a Supreme Court decision) would likely shed more light into other characteristics of what is patentable subject matter in the context of computerimplemented invention.

In the two years post-Alice, the Federal Circuit has released 26 opinions on $\S 101$ but out of those 26, only 2 opinions upheld patent validity (DDR Holdings and Enfish). However, past failures do not predict future results, ${ }^{125}$ as Enfish has ignited an optimistic fire in many software patent owners. ${ }^{126}$ Enfish (and BASCOM), which came out very late toward Alice's two-year anniversary, ${ }^{127}$ could mark a significant turning point for the fate of software patents. Before Enfish, many plaintiffs cited DDR Holdings in attempt to analogize their patents to the patent in DDR Holdings. However, this strategy mostly did not work, as seen by the similar invalidation rate in Alice's second year as compared to Alice's first year. Now with Enfish and DDR Holdings (in combination with BASCOM) as ammunition, plaintiffs would foreseeably have more of a shot to win the $\S 101$ battle. ${ }^{128}$

\footnotetext{
${ }^{120}$ Id. at ${ }^{*} 1$.

${ }^{121}$ Id. at ${ }^{*} 4$ (citing Enfish, LLC v. Microsoft Corp., No. 2015-1244, 2016 WL 2756255, at *11 (Fed. Cir. May 12, 2016)).

${ }^{122} I$ Id. at $* 4$.

${ }^{123} \mathrm{Id}$. at $* 5$.

${ }^{124}$ Id. at ${ }^{*}$. The Federal Circuit "[1]eft unclear [] the meaning of this discussion: does one only get to the solution to a technological problem inquiry if the claims are not directed to a specific improvement to computer functionality? Or is the analysis more flexible than Enfish implies?" Rantanen, supra note 114.

${ }^{125}$ Cf. Jasper L. Tran, The Law and 3D Printing, 31 J. Marshall J. Info. Tech. \& Privacy L. 505, 511 (2015) (“Past performance in law and 3D printing scholarship may not predict future returns in the field"). For a discussion on 3D Printing, see generally Jasper L. Tran, To Bioprint or Not to Bioprint, 17 N.C. J.L. \& TECH. 123 (2015) (covering 3D bioprinting); Jasper L. Tran, 3DPrinted Food, 17 Minn. J.L. Sci. \& Tесн. 855 (2016) (covering 3D-printed food); Jasper L. Tran, Press Clause and 3D Printing, 14 Nw. J. Teсн. \& Intell. Prop. 75 (2016) (covering the First Amendment right of 3D printing).

${ }^{126}$ E.g., Joff Wild, After so much 101 Gloom Enfish Is a Major Step in the Right Direction, Says Former Microsoft Chief Patent Counsel, IAM (May 30, 2016), http:/ / www.iam-media.com/blog/Detail.aspx?g=81b12b32-c2b9-4b24-801c-b917d430d776.

${ }^{127}$ Enfish came out on May 12, 2016, shortly before Alice's two-year anniversary on June 19, 2016.

${ }^{128}$ It could be that Alice's holding was so hard for software patents (at roughly $80 \%$ invalidation rate) that it cannot get lower than that (as there is only one way left to go, i.e. to go back up). Given the Federal Circuit's release of Enfish and DDR Holdings, there could likely be an upswing of valid software patents in the coming years.
} 


\section{The USPTO's Reaction Immediately After Enfish and TLI Communica- tions}

Following Enfish and TLI Communications, the USPTO, on May 19, 2016, issued new guidance instructing examiners to immediately implement Enfish's reinterpretation of Alice/Mayo. ${ }^{129}$ The new guidance, on its face, instructs examiners to "develop wellreasoned, substantive rejections rather than conclusory rejections." ${ }^{130}$ The guidance emphasizes the Federal Circuit's recognition of Mayo / Alice step one in the Enfish framework: "comparisons to prior abstract idea determinations; a caution against operating at too high a level of abstraction of the claims, and the rejection of the tissue-paper argument that use of a computer automatically dooms the claim (it doesn't)."131

The guidance concludes with: "[W]hen performing an analysis of whether a claim is directed to an abstract idea (Step 2A), examiners are to continue to determine if the claim recites (i.e., sets forth or describes) a concept that is similar to concepts previously found abstract by the courts."132 However, "a claim is directed to an improvement in computer-related technology can demonstrate that the claim does not recite a concept similar to previously identified abstract ideas."133 Notably, the language used to include "a concept that is similar to concepts previously found abstract by the courts" and "not recite a concept similar to previously identified abstract idea," which are not much help, especially when used with the qualifier "can demonstrate."134 Essentially, the guidance says nothing new, as examiners still have broad power over rejecting patent claims as they see fit. ${ }^{135}$

\section{E. BASCOM v. AT\&T}

Eight days outside of Alice's two-year mark, the Federal Circuit released its third opinion that upheld the patent-eligibility of a software invention under Alice: BASCOM $v$. ATET. ${ }^{136}$ Although this opinion is slightly outside of Alice's two-year review, I would be remiss if I did not cover BASCOM.137

\footnotetext{
${ }^{129}$ Memorandum from Robert W. Bahr, Deputy Comm'r for Pat. Examining Pol'y of the U.S. Pat. \&Trademark Off. to Pat. Examining Corps. (May 19, 2016) [hereinafter USPTO New Guidance], available at http://www.uspto.gov/sites/default/ files/documents/ieg-may-2016_enfish_memo.pdf. This guidance is the latest in the series dating back to 2009 after Bilski v. Kappos.

${ }^{130}$ Daniel Young \& Jessica Colantonio, USPTO Provides Updates to Patent Subject Matter Eligibility Guidance, IPWATCHDOG (June 1, 2016), http://www.ipwatchdog.com/2016/06/01/uspto-updates-patent-subject-matter-eligibility-guidance/id= $69602 /$.

${ }^{131}$ Rantanen, supra note 114

${ }^{132}$ USPTO New Guidance, supra note 129, at 2 (emphasis added).

${ }^{133} I d$. (emphasis added).

${ }^{134} \mathrm{Id}$. (emphasis added).

${ }^{135}$ Relatedly, Gene Quinn of IPWatchdog "expect[s examiners] will point to the TLI Communications decision as meaning that the Enfish decision was nothing more than a blip on the radar in the same way that DDR Holdings was a blip on the radar screen." Gene Quinn, USPTO Gives Examiner Guidance in Light of Enfish v. Microsoft, IPWATchDog (May 19, 2016), http:/ / www.ipwatchdog.com/2016/05/19/uspto-guidance-enfish-v-microsoft/id=69275/.

${ }^{136}$ BASCOM Global Internet Services, Inc. v. AT \& T Mobility LLC, No. 2015-1763, 2016 WL 3514158 (Fed. Cir. June 27, 2016).

${ }^{137}$ Note that eight days after BASCOM, the Federal Circuit released a fourth opinion that upheld the patent-eligibility citing Alice: Rapid Litig. Mgmt. Ltd. v. CellzDirect, Inc., No. 2015-1570, 2016 WL 3606624 (Fed. Cir. July 5, 2016). However, given this patent is not directed to computer-implemented invention, but instead describes "an improved process of preserving hepatocytes," id. at *2, I will cover this opinion in depth in my three-year review.
} 
In BASCOM Global Internet Services, Inc. v. AT \& T Mobility LLC (June 27, 2016), ${ }^{138}$ the challenged patent "recite[s] a system for filtering Internet content, [where the] filtering system is located on a remote ISP server that associates each network account with (1) one or more filtering schemes and (2) at least one set of filtering elements from a plurality of sets of filtering elements, thereby allowing individual network accounts to customize the filtering of Internet traffic associated with the account." ${ }^{139}$ The district court invalidated this patent as directed to the abstract idea of "filtering content [because] content provided on the Internet is not fundamentally different from content observed, read, and interacted with through other mediums like books, magazines, television, or movies."140

The Federal Circuit vacated and remanded, finding that under Mayo / Alice step two, the claimed patent describes an inventive concept of "installation of a filtering tool at a specific location, remote from the end-users, with customizable filtering features specific to each end user," even though "the limitations of the claims, taken individually, recite generic computer, network and Internet components, none of which is inventive by itself." ${ }^{141}$ The Federal Circuit found this patent similar to one in DDR Holdings, ${ }^{142}$ because the instant invention "is not claiming the idea of filtering content simply applied to the Internet [but] instead claiming a technology-based solution (not an abstract-ideabased solution implemented with generic technical components in a conventional way) to filter content on the Internet that overcomes existing problems with other Internet filtering systems." ${ }^{143}$ Furthermore, the Federal Circuit distinguished the patent here with those in OIP Techs., Inc. v. Amazon.com, Inc. ${ }^{144}$ Intellectual Ventures I, ${ }^{145}$ Content Extraction E Transmission LLC v. Wells Fargo Bank, Nat. Ass' $n_{1}^{146}$ Ultramercial, Inc. v. Hulu, LLC, ${ }^{147}$ and Accenture Glob. Servs., GmbH v. Guidewire Software, Inc. ${ }^{148}$ because the claims here "do not preempt the use of the abstract idea of filtering content on the Internet or on generic computer components performing conventional activities, [but] carve out a specific location for the filtering system (a remote ISP server) and require the filtering system to give users the ability to customize filtering for their individual net-

\footnotetext{
${ }^{138} 2016$ WL 3514158. It might be important to note that a panel of Judges Chen, O'Malley, and Newman resided over this case, with Judge Chen writing for the Court and Judge Newman concurring. Id. 
work accounts." ${ }^{149}$ Accordingly, the Federal Circuit found this invention recite patenteligible subject matter under Alice, ${ }^{150}$ making this case the third Federal Circuit case that upheld patent validity since Alice.

Takeaway. The Federal Circuit's behavior toward Alice's two-year mark is worth paying attention to. ${ }^{151}$ BASCOM clarifies when to transition from the Mayo / Alice step one to step two: when step one includes reasonable arguments on either side as to whether a claim is directed to an abstract idea, step two can resolve the question of patent eligibility. ${ }^{152}$ In response to $\S 101$ rejections, patent prosecutors can argue (1) under Enfish, the claim is unambiguously directed to a technological improvement, thus, eligible under step one, and (2) with step two as a fallback argument under BASCOM, that even if step one is a "close call," the claim still recites patent-eligible subject matter because "the specific arrangement of features in the claim improves a technological process." 153

\section{Conclusion}

As of June 19, 2016, courts have examined 568 challenged patents brought under $\S 101$ motions citing Alice, resulting in 190 valid patents and 378 patents invalidated with an average invalidation rate of $66.5 \%$. Specifically, the Federal Circuit upheld 3 patents and invalidated 34 patents-an average invalidation rate of $91.9 \%$. Also, courts have decided a total of 500 motions brought under $\S 101$ citing Alice, resulting in 109 validation holdings and 391 invalidation holdings with an average invalidation rate of $78.2 \%$. Specifically, the Federal Circuit has decided 26 motions, resulting in 2 validation holdings and 24 invalidation holdings with an average invalidation rate of $92.3 \%$. The district courts have decided 251 motions, resulting in 84 validation holdings and 167 invalidation holdings with an average invalidation rate of $66.5 \%$. The PTAB has decided 209 motions, resulting in 23 validation holdings and 186 invalidation holdings with an average invalidation rate of $89.7 \%$. In summary, the average invalidation rate of patents before the three venues was $82.9 \%$ at Alice's one-year and $78.2 \%$ at Alice's two-year, which could be attributed to the Federal Circuit's release of DDR Holdings.

The Enfish analysis reframes the Mayo/Alice step one inquiry into a bright-line dichotomy of "whether the focus of the claims is on the specific asserted improvement in computer capabilities . . . or, instead, on a process that qualifies as an "abstract idea" for which computers are invoked merely as a tool." In Enfish, the Federal Circuit made clear that it was "not persuaded that the invention's ability to run on a general-purpose computer dooms the claims." BASCOM clarifies when to transition from the Mayo/Alice step one to step two. Together, Enfish and BASCOM (in addition to DDR Holdings) mark

\footnotetext{
${ }^{149}$ BASCOM, 2016 WL 3514158 , at ${ }^{* 8}$.

${ }^{150} \mathrm{Id}$.

${ }^{151}$ Cf. Jasper L. Tran, The Right to Attention, 91 InD. L.J. 1023 (2016). It's almost as though the Federal Circuit is trying to stanch Alice's bleeding, one case at a time. E.g., Richard Lloyd, Some Hope for Software Patents in the US After the CAFC's Enfish Decision, But This Is No Game-Changer, IAM (May 13, 2016), http://www.iam-media.com/blog/detail.aspx?g=96d9253e7c06-418c-b3ec-3251497a7eac ("The Federal Circuit will continue, valiantly, to contain, limit and marginally reduce the harm. But, it will not be enough. That is the lesson of Enfish.").

${ }^{152}$ Albert W. Vredeveld, Alice Step 2 Eligibility Refined by Federal Circuit: Bascom Global Internet Services, Inc. v. AT\&T Mobility LLC, SHuMAKER \& SiefFerT News, http:/ /www.ssiplaw.com/news/201606/alice-step-2-eligibility-refined-federalcircuit-bascom-global-internet-services-inc-v.$$
{ }^{153} \text { Id. }
$$ 
a significant turning point for the fate of software patents. Given the late release of Enfish and BASCOM at the end of Alice's two-year anniversary, the downward trend in invalidation rates could continue in Alice's third year.

Stay tuned!

\section{Appendix A}

In my one-review year, I listed the information of the patents or patent applications that withstand the Alice test because these challenged patents or patent applications could be useful to patent prosecutors to study and learn how to draft more meaningful claims. ${ }^{154}$ For instance, based on statistical analysis of $\S 101$ rejections under Alice, a computer program can utilizes machine learning to predict subject matter rejections of patent claims. ${ }^{155}$ Similarly, Appendix A below provides the information of the patents or patent applications that courts (namely district courts, the PTAB and the Federal Circuit) have upheld under Alice from June 20, 2015 to June 19, 2016.

\begin{tabular}{|c|c|c|c|c|}
\hline $\begin{array}{l}\text { Patent No. or } \\
\text { Patent App. No. }\end{array}$ & Cases & Court & Holding & Reasoning \\
\hline $11 / 633,647$ & $\begin{array}{c}\text { Ex Parte Edvard Sorgard, Borgar } \\
\text { Ljosland, Jorn Nystad, Mario Blazevic, } \\
\text { Frank Langtind } \\
\text { (Decision on Appeal) } \\
\text { 2012-012464 } \\
\text { Date: July 16, } 2015\end{array}$ & РTAB & upheld & Not Abstract \\
\hline $12 / 765,954$ & $\begin{array}{l}\text { Ex Parte Cyriac J. Wegman III } \\
\text { (Decision on Appeal) } \\
\text { 2013-008168 } \\
\text { Date: September } 18,2015\end{array}$ & РTAB & upheld & Not Abstract \\
\hline $\begin{array}{c}6,998,977 \text { and } \\
7,852,212 \text { and } \\
8,144,011 \text { and } \\
7,489,923 \text { and } \\
7,876,218\end{array}$ & $\begin{array}{l}\text { The Chamberlain Group, Inc., v. Linear } \\
\text { LLC (Memorandum Opinion) } \\
\text { ILND-1-14-cv-05197 } \\
\text { Date: July 7, } 2015\end{array}$ & DC & upheld & Not Abstract \\
\hline $\begin{array}{c}8,393,007 \text { and } \\
8,370,956 \text { and } \\
7,523,072 \text { and } \\
7,269,576 \text { and } \\
6,963,859 \text { and } \\
7,774,280 \text { and } \\
8,001,053\end{array}$ & $\begin{array}{l}\text { ContentGuard Holdings, Inc., v. } \\
\text { Amazon.com, Inc. } \\
\text { (Memorandum Opinion and Order) } \\
\text { TXED-2-13-cv-01112, } \\
\text { TXED-2-14-cv-00061 } \\
\text { Date: August 6, } 2015\end{array}$ & DC & upheld & Not Abstract \\
\hline $6,101,502$ & $\begin{array}{l}\text { Datatern, Inc., v. Microstrategy, Inc., et } \\
\text { al. (Memorandum Order) } \\
\text { MAD-1-11-cv-12220 } \\
\text { Date: September 4, } 2015\end{array}$ & DC & upheld & Not Abstract \\
\hline
\end{tabular}

\footnotetext{
${ }^{154}$ Tran, One-Year Review, supra note 7, at 546-50.

${ }^{155}$ Ben Dugan, Ask Alice!, available at http://alice.cebollita.org:8000/predict (including a few pre-loaded claims from well-known cases).
} 


\begin{tabular}{|c|c|c|c|c|}
\hline $\begin{array}{c}\text { Patent No. or } \\
\text { Patent App. No. }\end{array}$ & Cases & Court & Holding & Reasoning \\
\hline $\begin{array}{c}\text { RE44,956 and } \\
\text { RE44,973 }\end{array}$ & $\begin{array}{l}\text { Canrig Drilling Technology LTD., v. } \\
\text { Trinidad Drilling L.P. } \\
\text { (Memorandum Order) } \\
\text { TXSD-4-15-cv-01821 } \\
\text { Date: September 17, } 2015\end{array}$ & DC & upheld & Not Abstract \\
\hline $5,659,891$ & $\begin{array}{l}\text { Mobile Telecommunications } \\
\text { Technologies, LLC, v. Leap Wireless } \\
\text { International, Inc. } \\
\text { (Memorandum Order) } \\
\text { TXED-2-13-cv-00885 } \\
\text { Date: September 23, } 2015\end{array}$ & DC & upheld & Not Abstract \\
\hline $\begin{array}{c}8,572,279 \text { and } \\
8,601,154\end{array}$ & $\begin{array}{c}\text { SimpleAir, Inc., v. Google Inc. } \\
\text { (Memorandum Opinion and Order) } \\
\text { TXED-2-14-cv-00011 } \\
\text { Date: September 25, } 2015\end{array}$ & DC & upheld & Not Abstract \\
\hline $\begin{array}{l}7,631,346 \text { and } \\
5,961,601 \text { and } \\
5,796,967 \text { and } \\
7,072,849\end{array}$ & $\begin{array}{l}\text { International Business Machines } \\
\text { Corporation v. The Priceline Group Inc. } \\
\text { (Report and Recommendation) } \\
15-137 \\
\text { Date: February 16, } 2016\end{array}$ & DC & upheld & Not Abstract \\
\hline $\begin{array}{c}7,579,141 \text { and } \\
8,021,832 \text { and } \\
8,974,800\end{array}$ & $\begin{array}{c}\text { Rutgers v. Qiagen N.V. } \\
\text { (Memorandum Order) } \\
\text { NJD-15-cv-7187 } \\
\text { Date: February 29, } 2016\end{array}$ & DC & upheld & Not Abstract \\
\hline $7,058,439$ & $\begin{array}{l}\text { ContourMed Inc., v. American Breast } \\
\text { Care L.P. } \\
\text { (Memorandum Opinion and Order) } \\
\text { TXSD-4-15-cv-02769 } \\
\text { Date: March 17, } 2016\end{array}$ & DC & upheld & Not Abstract \\
\hline $6,130,761$ & $\begin{array}{c}\text { Intellectual Ventures I LLC, v. Ricoh } \\
\text { Americas Corporation } \\
\text { (Memorandum Opinion) } \\
\text { DED-1-13-cv-00474 } \\
\text { Date: March 22, } 2016\end{array}$ & DC & upheld & Not Abstract \\
\hline $\begin{array}{c}6,604,101 \text { and } \\
7,516,154\end{array}$ & $\begin{array}{l}\text { Improved Search LLC, v. AOL Inc. } \\
\text { (Memorandum Opinion) } \\
\text { DED-1-15-cv-00262 } \\
\text { Date: March 22, } 2016\end{array}$ & DC & upheld & Not Abstract \\
\hline $\begin{array}{c}6,711,615 \text { and } \\
6,484,203\end{array}$ & $\begin{array}{l}\text { SRI International, Inc., v. Cisco Systems, } \\
\text { Inc. (Memorandum Opinion) } \\
\text { DED-1-13-cv-01534 } \\
\text { Date: April 11, } 2016\end{array}$ & DC & upheld & Not Abstract \\
\hline $\begin{array}{c}5,764,034 \text { and } \\
6,321,560\end{array}$ & $\begin{array}{c}\text { Baxter International, Inc., v. Carefusion } \\
\text { Corp. (Memorandum and Order) } \\
\text { ILND-1-15-cv-09986 } \\
\text { Date: May 13, } 2016\end{array}$ & DC & upheld & Not Abstract \\
\hline $\begin{array}{c}6,891,566 \text { and } \\
8,185,964\end{array}$ & $\begin{array}{c}\text { JDS Technologies, Inc., v. Exacq } \\
\text { Technologies (Memorandum and Order) } \\
\text { MIED-2-15-cv-10387 } \\
\text { Date: June 7, } 2016\end{array}$ & DC & upheld & Not Abstract \\
\hline
\end{tabular}




\begin{tabular}{|c|c|c|c|c|}
\hline $\begin{array}{c}\text { Patent No. or } \\
\text { Patent App. No. }\end{array}$ & Cases & Court & Holding & Reasoning \\
\hline $13 / 079,976$ & $\begin{array}{l}\text { Ex Parte Jonah C. Kagen } \\
\text { (Decision on Appeal) } \\
\text { 2013-008188 } \\
\text { Date: December 18, } 2015\end{array}$ & PTAB & upheld & $\begin{array}{l}\text { Significantly } \\
\text { More than the } \\
\text { Abstract Idea } \\
\text { Itself }\end{array}$ \\
\hline $11 / 477,767$ & $\begin{array}{c}\text { Ex Parte Juha Kallio } \\
\text { (Decision on Appeal) } \\
\text { 2014-005647 } \\
\text { Date: March 17, } 2016\end{array}$ & РTAB & upheld & $\begin{array}{l}\text { Significantly } \\
\text { More than the } \\
\text { Abstract Idea } \\
\text { Itself }\end{array}$ \\
\hline $\begin{array}{c}6,151,604 \text { and } \\
6,163,775\end{array}$ & $\begin{array}{c}\text { Enfish, LLC v. Microsoft Corp. } \\
\text { 2015-1244 } \\
\text { Date: May 12, } 2016\end{array}$ & Fed. Cir. & upheld & $\begin{array}{l}\text { Significantly } \\
\text { More than the } \\
\text { Abstract Idea } \\
\text { Itself }\end{array}$ \\
\hline $6,259,789$ & $\begin{array}{c}\text { Luciano F. Paone, v. Broadcom } \\
\text { Corporation (Memorandum Decision } \\
\text { and Order) } \\
\text { NYED-2-15-cv-00596 } \\
\text { Date: August 19, } 2015\end{array}$ & DC & upheld & $\begin{array}{l}\text { Significantly } \\
\text { More than the } \\
\text { Abstract Idea } \\
\text { Itself }\end{array}$ \\
\hline $\begin{array}{c}8,597,678 \text { and } \\
8,709,494\end{array}$ & $\begin{array}{c}\text { MiMedX Group, Inc., v. Nutech Medical, } \\
\text { Inc. (Memorandum Opinion and Order) } \\
\text { ALND-2-15-cv-00369 } \\
\text { Date: November 24, } 2015\end{array}$ & DC & upheld & $\begin{array}{l}\text { Significantly } \\
\text { More than the } \\
\text { Abstract Idea } \\
\text { Itself }\end{array}$ \\
\hline $8,285,678$ & $\begin{array}{l}\text { Motio, Inc., v. BSP Software, LLC } \\
\text { (Memorandum Opinion and Order) } \\
\text { TXED-4-12-cv-00647 } \\
\text { Date: January 4, } 2016\end{array}$ & DC & upheld & $\begin{array}{l}\text { Significantly } \\
\text { More than the } \\
\text { Abstract Idea } \\
\text { Itself }\end{array}$ \\
\hline $6,826,620$ & $\begin{array}{l}\text { Network Congestion Solutions, LLC, v. } \\
\text { United States Cellular Corporation } \\
\text { (Memorandum Opinion) } \\
\text { DED-1-14-cv-00903 } \\
\text { Date: March 22, } 2016\end{array}$ & DC & upheld & $\begin{array}{l}\text { Significantly } \\
\text { More than the } \\
\text { Abstract Idea } \\
\text { Itself }\end{array}$ \\
\hline $\begin{array}{c}6,292,685 \text { and } \\
7,787,923\end{array}$ & $\begin{array}{l}\text { Exergen Corporation, v. Kaz USA, Inc. } \\
\text { (Memorandum and Order) } \\
\text { MAD-1-13-cv-10628 } \\
\text { Date: March 25, } 2016\end{array}$ & DC & upheld & $\begin{array}{l}\text { Significantly } \\
\text { More than the } \\
\text { Abstract Idea } \\
\text { Itself }\end{array}$ \\
\hline
\end{tabular}

